\title{
A Stochastic Frontier Approach (SFA) For Measuring Efficiency of Syariah Rural Bank (BPRS) in Aceh, Indonesia
}

\author{
Early Ridho Kismawadi1, Amiur Nuruddin2, Muhammad Yusuf3 \\ IPhD Student in Syariah Economic Program, Islamic State University of North Sumatera, Indonesia \\ 2 Lecturer in Syariah Economic Program, Islamic State University of North Sumatera, Indonesia \\ 3 Lecturer in Faculty of Economic, Medan State University, Indonesia
}

\begin{abstract}
This paper discussed the efficiency of Syariah people's credit bank (BPRS) in Aceh using stochasticfrontier approach (SFA). Before calculating such efficiency, the input and output variables were first bedetermined using the intermediation approach. The input variables were fixed asset, personnel costs, and total deposit, whereas output variables were total financing and certificates of deposit. During the observation period (January 2012 to March 2016 (quarterly)) of every BPRS in Aceh, amounting to 10 banks, Bank 4 had thehighest mean efficiency score with 0.953 or $95.3 \%$. Behind it was Bank 1 with $0.912(92.1 \%)$. Banks 3 and 7 recorded the lowest efficiency score with $0.522(52 \%)$ and $0.543(54 \%)$ respectively.
\end{abstract}

Keywords - Stochastic frontier approach, efficiency, Syariah bank

\section{INTRODUCTION}

The long-term sustainability of Islamic banks depends on efficiency. Economically, an Islamic bank isefficient if it demonstrates technical and cost efficiency [1]. Long-term sustainability hinges on economicefficiency. A bank is economically efficient if it is both cost and technically efficient. A technically efficientcompany is one that produces a relatively larger output from the same amount of input [2]. Bank risk mayincrease in the future if there was a decrease in technical and cost efficiency. Conversely, a higher efficiencyenables the bank to sustain capital better. Previous studies have shown that banks with low efficiency borehigher risk and had weaker short-term capital position [3]. The NPF (Non Performing Financing) of BUS and UUS were lower than that of BPRS. In January2015, the NPF of BUS and UUS was 6.5\%. The subsequent months saw lower numbers with $6.45 \%$ in February, 5.66\% in June, and $5.14 \%$ in December. BPRS, on the other hand, had higher NPF. It recorded its NPF at $13.01 \%$ in January, $13.46 \%$ in February, and then dropped to $12.22 \%$ in June and $8.76 \%$ in December. Despitethese diminishing numbers, the fact remains that BPRS' NPF was still higher relative to that of BUS and UUS.

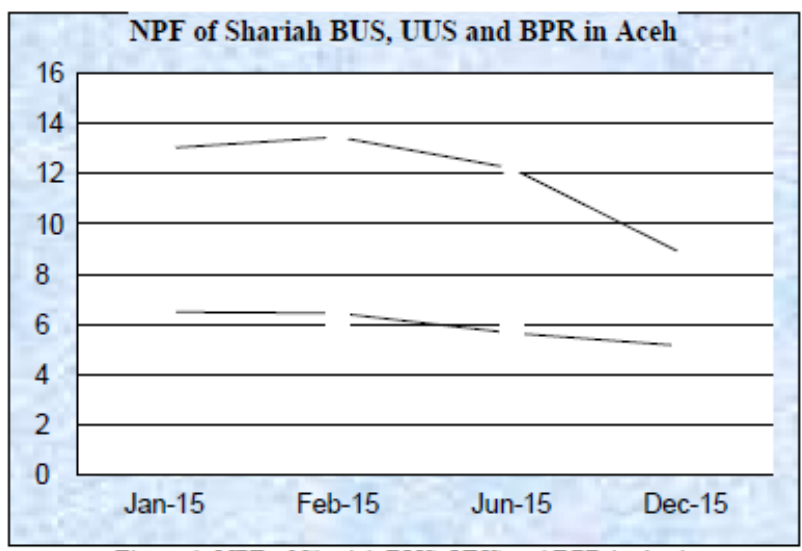

Figure 1. NPF of Shariah BUS, UUS and BPR in Aceh

Source: Financial Services Authority (OJK)

Among the three BPRS's in Aceh, only one constantly generated profit over a five-year period. Another BPRS only managed to gain some profit in 2015, while making losses in the remaining three years. Thelast BPRS was in between, as it reported some profit in 2012 and 2015, and losses in 2013 and 2014. 


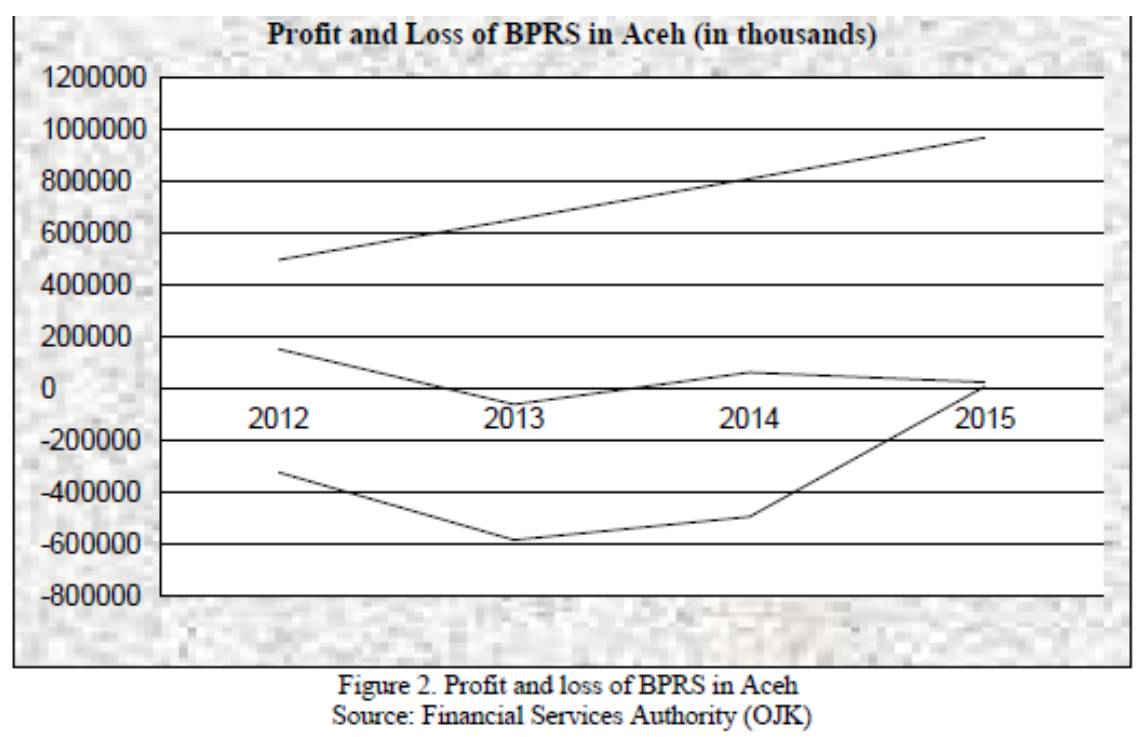

Efficiency is a quite popular indicator of performance in the banking world, since it serves to answerthe difficulties in calculating bank performance measurements. The ratio of operating cost to operating profit (OER) has been used as an indicator to measure efficiency. One of the main benefits of this ratio is its simplicity [4]. However, it also has its own weaknesses in calculating efficiency. Financial ratios only highlight certain aspects of a bank's activities. Since the banking industry usesseveral inputs to produce several outputs, a precise conclusion would not necessarily be obtained using financialratios. To circumvent this obstacle, there needs to be an alternative technique that is able to calculate the totalproductivity factor of a banking unit comprising every operational aspects of banking in a single measurement [5]. The alternative technique in question is stochastic frontier analysis (SFA).

\subsection{Research Scope}

\section{II. . METHODOLOGY}

This research used a quantitative approach; data was measured in a numeric scale based on timeseriesdata relating to efficiency. The data was obtained from financial statements from Bank Indonesia, indicating thatsecondary data was used in this research. The population of this study is data obtained from Bank Indonesiafrom January 2012 to March 2016 (quarterly reports). Sample was determined using purposive samplingsamplesare collected based on certain purposes and considerations. This sample was retrieved from IndonesiaCentral Bank (BI) and Financial Service Authority (OJK) in the form of financial statements (balance sheet andincome statement) of every BPR Syariah in Aceh, which amounted to 10 BPR Syariah.

\subsection{Data Collection}

The method of data collection can be stated as below:

1. Field research

The data is secondary data collection by a data collection agency and it is published to the communitywho uses data. The data is refered from Indonesia Central Bank (Bank Indonesia) and Financial ServiceAuthority (Finance Services).

\section{Internet research}

Reference or literature borrowed from library is some time not up to date. It is due to the knowledge isalways growth. Thus, an internet acces is very important to obtain the latest data information related to thisresearch.

\subsection{Data Analysis Method}

The data was then analyzed using stochastic frontier approach (SFA). In an SFA approach, theinefficiency component and random error from composite error term were separated by an explicit assumptionon its spread. Berger and Mester stated that in an SFA approach, cost efficiency gives a measure of how close abank's cost is to what a best-practice bank's cost would be for producing the same output using the sametechnology [6]. It is required in a parametric approach to determine the cost function as a condition to calculatethe limit. The cost function model in this study was the maximum likelihood model in the form of 
flexibletranslog cost function on the second order [6]. The input and output variables in this study were determinedusing the intermediation approach. This intermediation approach focused on bank production from intermediation services and productioncost total, including interest (profit sharing) and operating cost. Input is usually defined as labour, physicalcapital, deposit, and other types of loan funds. In several other studies, equity capital was also included. Depositwas treated as input in an intermediation approach [7].

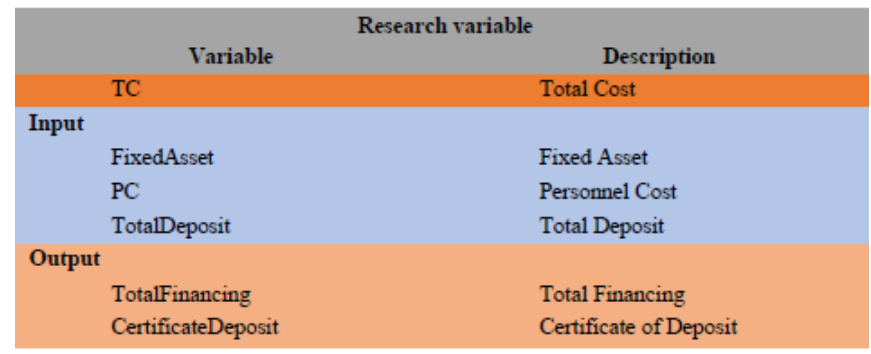

Figure 3. Research variable in list

Stochastic frontier approach (SFA) is a parametric statistic that uses econometric methods employingCobb-Douglas production function form. It is one of the methods for estimating frontier functions in efficiencyof production [8]. SFA is notable in that it allows some frontier deviation caused by external factors, such asweather, natural disaster, luck, and measurement error in the dependent variable [9]. SFA uses a frontier tomeasure the efficiency of a bank. A bank is said to be inefficient if the cost level of a bank is higher than that ofa best-practice bank on the frontier [10].SFA posits a composed error model where inefficiencies were assumed to follow an asymmetricdistribution, usually the half-normal, while random errors follow a symmetric distribution, usually the standardnormal[11]. Therefore, the error composite term can be given as e $i=\mu+v$, where $\mu>0$ represents half-normaldistributed inefficiency, while $v$ represents normal distributed random error [11].The cost function calculated in this study was the Cobb-Douglas form, seeing that this function hasbeen used considerably in illustrating the relationship between input and output. Referring to [6], the Cobb-

Douglas function equation is as follows:

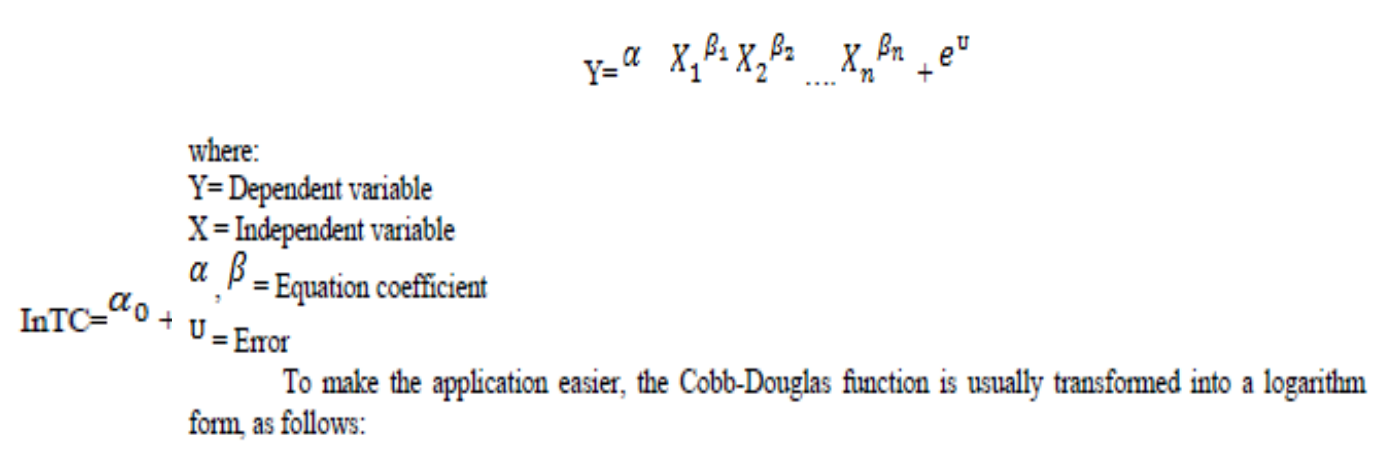

$$
\begin{aligned}
& \log \mathrm{Y}=\log \alpha_{+} \beta 1 \log X_{1}+\beta 2 \log \quad X_{2+} \mathrm{u} \log e \\
& \operatorname{InTC}=\alpha_{0} \sum_{j=i}^{2} \alpha_{0} \ln \left(y_{i}\right)+\sum_{k=i}^{3} \beta_{k} \ln \left(p_{k}\right)+\operatorname{In} u+\operatorname{In} \mathrm{v}
\end{aligned}
$$

where:

$\mathrm{Tc}=$ total cost, i.e. operating cost consisting of wadiah deposit bonus, general administrative expense, operating expense, provision for loan losses, other expenses, and non-operating expense.

Y1 = financing, comprised of Murabahah, Mudharabah, Musyarakah, Istishna', and Qardhul Hasan.

Y2= commercial papers owned.

$\mathrm{P} 1=$ resource cost, i.e. cost incurred from the use of human resources, such as wage.

$\mathrm{P} 2=$ cost of finance, i.e. cost incurred from the use of third-party funds, such as margin for depositors and bonus for wadiah consignment. 
P3 = cost of physical capital, i.e. cost incurred from the use of physical asset, such as depreciation and maintenance.

$u=$ measure of inefficiency.

$\mathrm{v}=$ statistical noise.

Efficiency variable is calculated with the following equation:

$\mathrm{CEFF}=1-$

where INEFF is inefficiency.

The cost efficiency ratio of a bank can be formulated as follows:

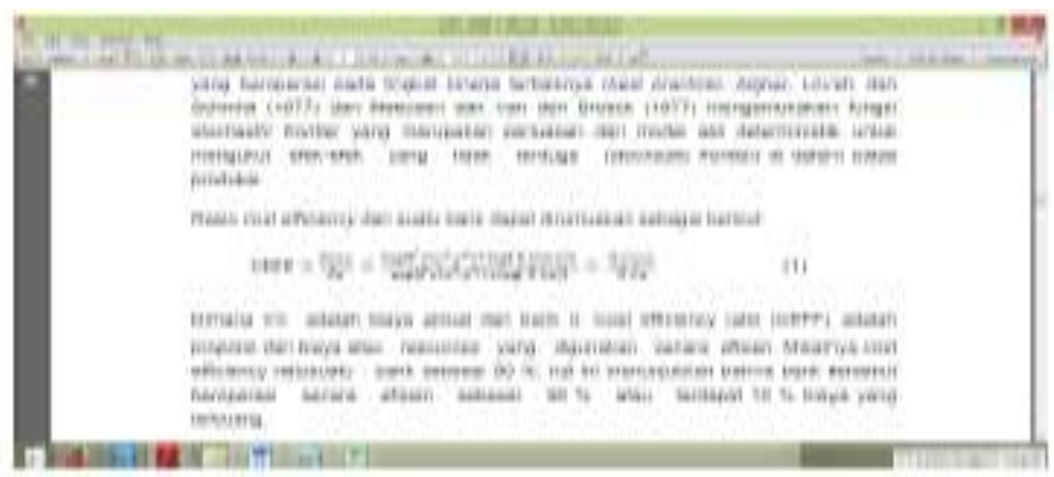

$\mathrm{Cn}$ is the actual cost expended by bank $n$. Cost efficiency ratio illustrates the proportion of an efficientlyincurred cost or used resource. If the cost efficiency ratio amounts to $99 \%$, it indicates that the bank operates at $99 \%$ efficiency, while the remaining $1 \%$ is lost.

\section{RESULT AND DISCUSSION}

\subsection{Growth of third-party funds in BPRS}

BPRS' third-party funds in January 2013 amounted to Rp51,352 million. The same amount wasrecorded for February 2013. March 2013 saw a slight increase with Rp52,408 million. In April 2013, itdecreased to Rp51,408 million, and finally increased to Rp53,847 million in June. In July 2013, the total thirdparty funds were Rp53,382 million, and in August 2013 it slightly rose toRp54.94 million. In September 2013, it was recorded as Rp55.241 million, and in October 2013 there wasanother increase to Rp56,880 million. In the subsequent month, the total reached Rp56,994 million, and in thelast month of the year, the total amount was Rp60,273 million.

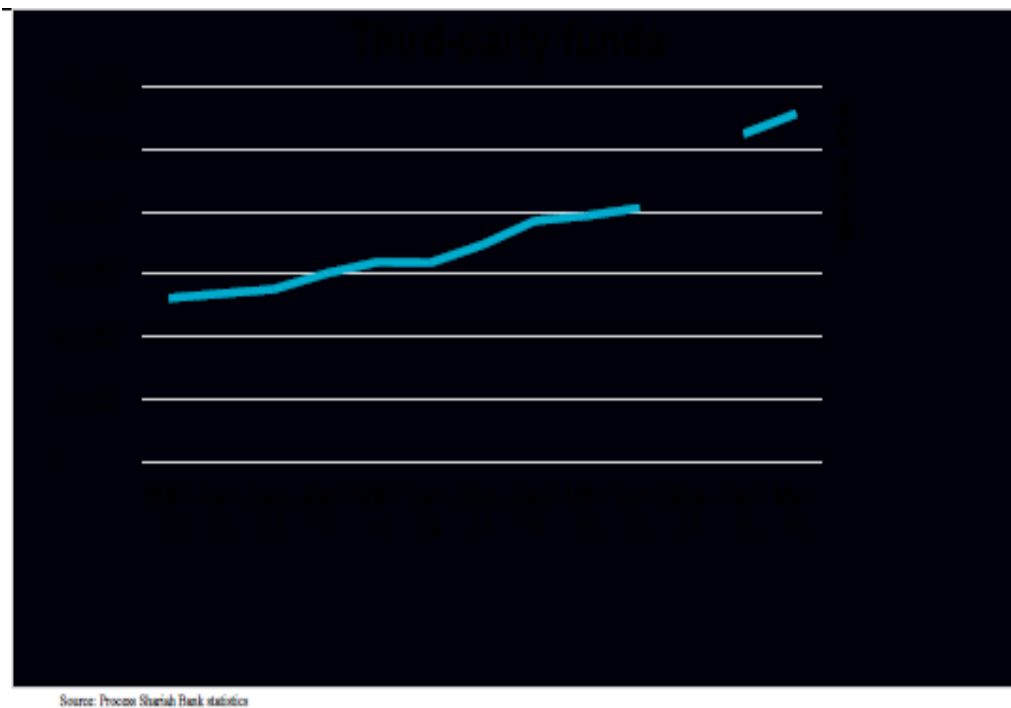

Figure 4. Total third-party funds of BPRS

The total third-party funds of BPRS in January 2016 was Rp105,476 million, a significant year-onyearincrease, as January 2015 only saw Rp78,114 million. In February 2016, the amount totalled to Rp111,977million, a significant year-on-year increase, as February 2015 recorded only Rp79,083 million. The

DOI: $10.9790 / 0837-2205073743 \quad$ www.iosrjournals.org $\quad 40 \mid$ Page


amount forthe subsequent month was Rp111,303 million. Compared to March 2014's amount of Rp78,737 million, therewas a noteworthy year-on-year growth. The following April and May 2016 saw decreases in the total amount ofthird-party funds with Rp109,882 million and Rp108,783 million respectively. Nonetheless, both were stillarger compared with the same months during the previous year.

\subsection{Comparison of BPR Syariah Financing by Utilization}

BPRS financed working capital more than investment or consumption. In January 2013, the recordedworking capital financing was Rp107,192 million - a significant jump compared with Rp1,762 million andRp12,682 million financed investment and consumption, respectively. In the same month, $88.12 \%$ of financingwas for working capital, $1.44 \%$ for investment, and $10.42 \%$ for consumption.

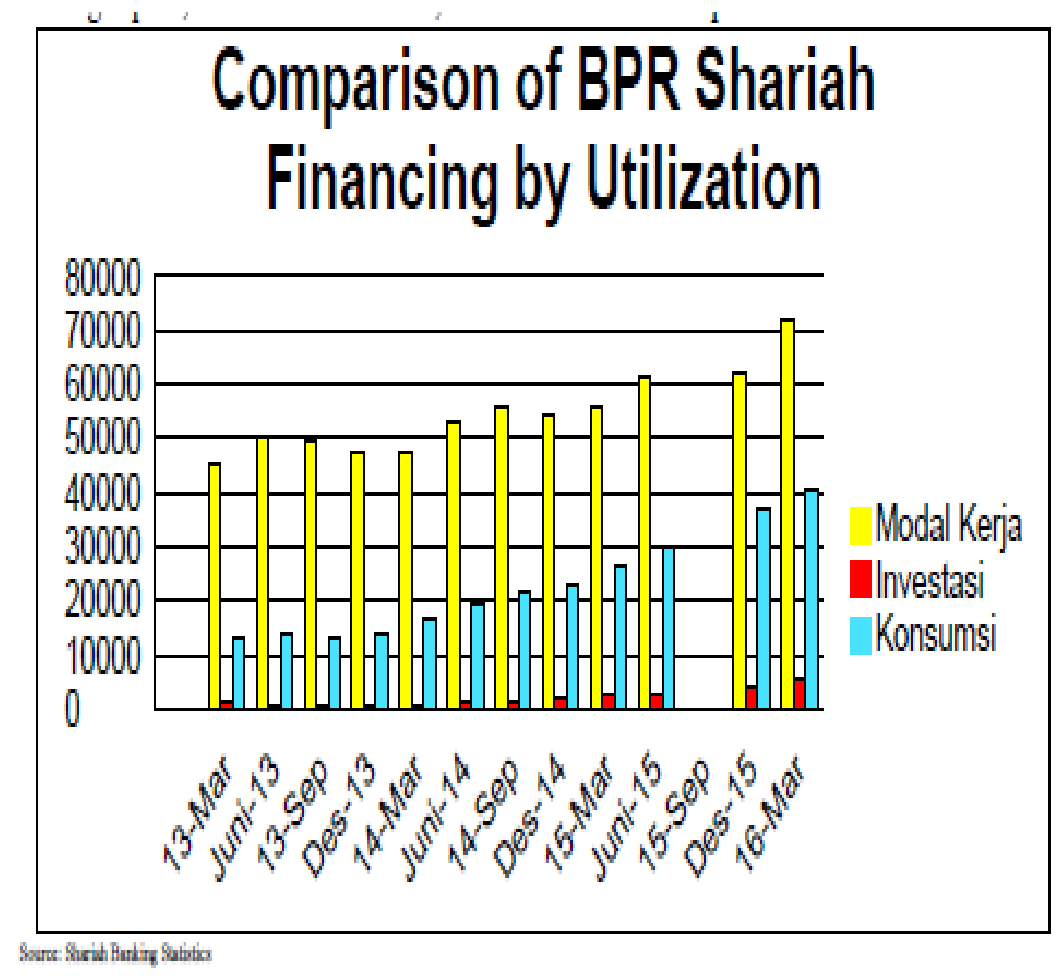

Figure 5. Comparison of BPR Shariah Financing by Utilization

A similar trend was found in the following month. In February 2013, the recorded working capitalfinancing was Rp4,404 million compared with Rp1,128 million and Rp12,682 million financed investment andconsumption, respectively. In the same month, 76.36\% of financing was for working capital, $1.93 \%$ forinvestment, and $21.69 \%$ for consumption. Based on the percentages, working capital financing still dominateddespite a slight decline.BPRS finances working capital far more than investment or consumption. In September, October, andDecember 2013, the recorded working capital financing was Rp49,487 million, Rp49,212 million, and Rp47,308million, respectively, compared with Rp834 million and Rp13,514 million financed investment andconsumption, respectively, in September.Nonetheless, investment and consumption financing were increasing - in April 2016, the share ofinvestment financing was $5.07 \%$ and $4.61 \%$, an increase compared with April 2015 and higher compared withthe previous month. The share of consumption financing in April 2016 was 5.07\% and in May 4.61\%, anincrease compared with April 2015 and higher compared with the previous month.

\subsection{Calculation of Efficiency using SFA}

The table below shows that the mean efficiency of Bank 1 was 0.912 , with a maximum efficiency of0.985 and minimum efficiency of 0.799 . The values indicated that the mean efficiency of Bank 1 was $91.2 \%$, with a maximum efficiency of $91.2 \%$ in Q3 of 2014 and minimum efficiency of 79.9\%.The mean efficiency of Bank 3 was 0.953, with a maximum efficiency of 0.889 in Q2 of 2013 andminimum efficiency of 0.522 in Q1 of 2016. The values indicated that during the observation period, the meanefficiency of Bank 3 was $73.6 \%$, maximum efficiency of $88.9 \%$, and minimum efficiency of $5.22 \%$. 


\begin{tabular}{|c|c|c|c|c|c|c|c|c|c|c|}
\hline Minimum & 0.799 & 0.702 & 0.522 & 0.898 & 0.785 & 0.76 & 0.543 & 0.695 & 0.686 & 0. \\
\hline Maximum & 0.985 & 0.981 & 0.889 & 0.977 & 0.975 & 0.93 & 0.976 & 0.96 & 0.977 & \\
\hline \multicolumn{11}{|c|}{ Code Shariah Rural Banks } \\
\hline Period & 1 & 2 & 3 & 4 & 5 & 6 & 7 & 8 & 9 & 10 \\
\hline $\mathrm{K} 1: 2012$ & 0.930 & 0.835 & 0.873 & 0.972 & 0.874 & 0.763 & 0.912 & 0.804 & 0.881 & 0.932 \\
\hline $\mathrm{K} 2: 2012$ & 0.927 & 0.838 & 0.863 & 0.949 & 0.855 & 0.760 & 0.543 & 0.783 & 0.771 & 0.892 \\
\hline K3:2012 & 0.912 & 0.810 & 0.820 & 0.957 & 0.829 & 0.789 & 0.885 & 0.760 & 0.714 & 0.860 \\
\hline $\mathrm{K} 4: 2012$ & 0.825 & 0.728 & 0.781 & 0.936 & 0.785 & 0.817 & 0.834 & 0.737 & 0.686 & 0.789 \\
\hline $\mathrm{K} 1: 2013$ & 0.911 & 0.786 & 0.823 & 0.974 & 0.862 & 0.930 & 0.911 & 0.760 & 0.974 & 0.896 \\
\hline $\mathrm{K} 2: 2013$ & 0.936 & 0.798 & 0.889 & 0.965 & 0.889 & 0.820 & 0.927 & 0.732 & 0.902 & 0.937 \\
\hline K3:2013 & 0.936 & 0.736 & 0.704 & 0.957 & 0.847 & 0.798 & 0.924 & 0.704 & 0.841 & 0.904 \\
\hline $\mathrm{K} 4: 2013$ & 0.881 & 0.702 & 0.701 & 0.940 & 0.862 & 0.770 & 0.854 & 0.695 & 0.720 & 0.853 \\
\hline K1:2014 & 0.920 & 0.981 & 0.715 & 0.972 & 0.975 & 0.858 & 0.877 & 0.756 & 0.977 & 0.930 \\
\hline $\mathrm{K} 2: 2014$ & 0.968 & 0.853 & 0.730 & 0.963 & 0.939 & 0.822 & 0.878 & 0.784 & 0.959 & 0.908 \\
\hline K3:2014 & 0.985 & 0.930 & 0.696 & 0.946 & 0.924 & 0.820 & 0.874 & 0.810 & 0.861 & 0.863 \\
\hline $\mathrm{K} 4: 2014$ & 0.980 & 0.888 & 0.691 & 0.898 & 0.856 & 0.801 & 0.907 & 0.711 & 0.713 & 0.844 \\
\hline K1:2015 & 0.949 & 0.940 & 0.553 & 0.961 & 0.945 & 0.926 & 0.965 & 0.708 & 0.866 & 0.914 \\
\hline $\mathrm{K} 2: 2015$ & 0.928 & 0.907 & 0.735 & 0.969 & 0.950 & 0.919 & 0.976 & 0.699 & 0.912 & 0.918 \\
\hline K3:2015 & 0.845 & 0.872 & 0.732 & 0.956 & 0.953 & 0.909 & 0.963 & 0.721 & 0.870 & 0.949 \\
\hline $\mathrm{K} 4: 2015$ & 0.799 & 0.856 & 0.696 & 0.923 & 0.942 & 0.924 & 0.915 & 0.752 & 0.730 & 0.934 \\
\hline $\mathrm{K} 1: 2016$ & 0.886 & 0.936 & 0.522 & 0.977 & 0.967 & 0.927 & 0.962 & 0.960 & 0.821 & 0.979 \\
\hline Mean & 0.912 & 0.846 & 0.736 & 0.953 & 0.897 & 0.844 & 0.888 & 0.757 & 0.835 & 0.900 \\
\hline
\end{tabular}

The mean efficiency of Bank 4 was 0.953, with a maximum efficiency of 0.977 in Q1 of 2016 andminimum efficiency of 0.898 in Q4 of 2014. The values indicated that during the observation period, the meanefficiency of Bank 4 was $95.3 \%$, maximum efficiency of $97.7 \%$, and minimum efficiency of $89.8 \%$.The mean efficiency of Bank 10 was 0.900, with a maximum efficiency of 0.979 in Q1 of 2016 andminimum efficiency of 0.789 in Q4 of 2012. The values indicated that during the observation period, the meanefficiency of Bank 10 was $90 \%$, with a maximum efficiency of $97.9 \%$ and minimum efficiency of $78.9 \%$.

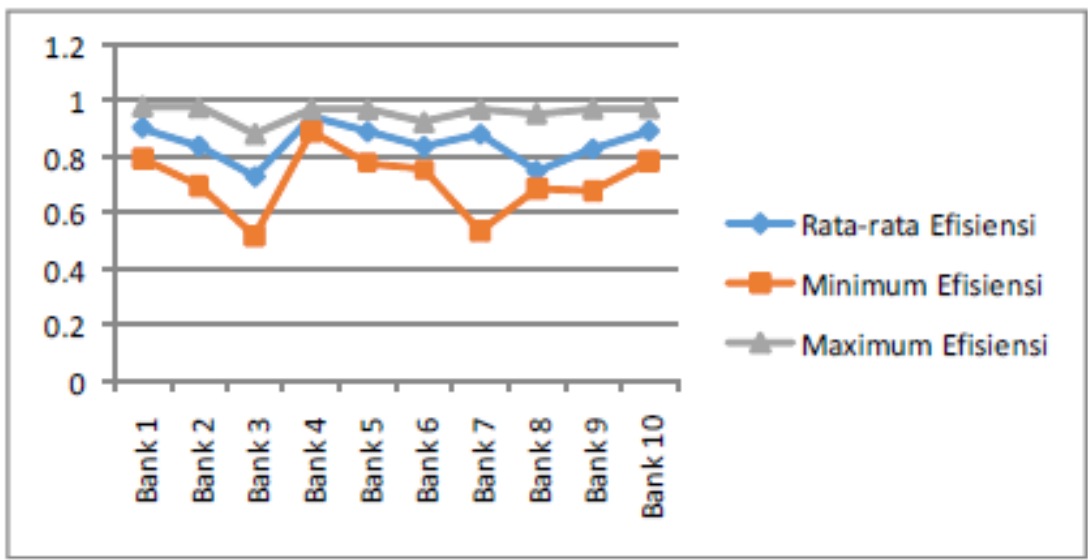

Figure 6. Summary of Efficiency during Observation

The figure above shows that during the observation period, Bank 4 had the best mean efficiency (CEFF $=0.953$ or $95.3 \%)$ followed by Bank $2(\mathrm{CEFF}=0.912$ or 92.1). Based on SFA to calculate the efficiency of BPRS, it was found that the mean efficiency of Bank 1 was $91.2 \%$, indicating an inefficiency of $8.8 \%$. The mean efficiency of Bank 2 during the observation period was $84.6 \%$, indicating an inefficiency of $15.4 \%$ and less 
efficient compared with BPRS 1BPR Syariah 3 was $73.6 \%$ efficient, far less efficient compared with BPR Syariah 1 and 2. BPRSyariah 4 was the most efficient at 95.3\% compared with other 9 BPR Syariahs; it was nonetheless 4.7\%inefficient. The mean efficiency of BPR Syariah 5 during the observation period was $89.7 \%$, indicating aninefficiency of $10.3 \%$. BPR Syariah 6 was less efficient than BPR Syariah 5 at $84.4 \%$ and outperformed by BPRSyariah 7 at $88.8 \%$. The mean efficiency of BPR Syariah 8 was less than $80 \%$ at $75.5 \%-$ an inefficiency of $24.5 \$$. The mean efficiency of BPR Syariah 9 was $83.5 \%$ and was outperformed by BPR Syariah 10 at $90 \%$.Despite that, BPR Syariah 10 was $10 \%$ inefficient.

\section{CONCLUSION}

Efficiency is defined as the ratio between output and input or in other words, a firm's ability to produceoutput using available input. An efficient firm indicates that it is able to maximize its resources to producemaximum profit, whereas an inefficient firm indicates that its allocation of resources leaves much to be desiredin terms of profit. In simpler terms, the more efficient a firm is, the more positive gains it can have.Based on efficiency calculations, it was found that there were 3 BPR Syariahs whose efficiency wasabove the 90th percentile: BPR Syariah 1, BPR Syariah 4, and BPR Syariah 10; 5 BPR Syariah whose efficiencywas in the 80th percentile: BPR Syariah 3, BPR Syariah 5, BPR Syariah 6, BPR Syariah 7, and BPR Syariah 9; and 2 BPR Syariah whose efficiency was in the 70th percentile: BPR Syariah 3 and BPR Syariah 7.

\section{REFERENCES}

[1] A Stochastic Frontier Approach (SFA) For Measuring Efficiency of Syariah Rural Bank (BPRS) in

[2] Aceh, Indonesia

[3] www.iosrjournals.org $8 \mid$ Page

[4] S. R. M. Rahim, How Efficient Are Islamic Banks in Malaysia?. Journal of Business Studies Quarterly 2015, Volume 6,

[5] Number 3. p. 164

[6] M. K. Hassan, The X-Efficiency In Islamic Banks, Islamic Economic Studies, vol. 13, no. 2, Pebruary 2006, h. 50

[7] F. Fiordelisi, Efficiensy And Risk In European Banking. European Central Bank, Working Paper Series. No 1211/June 2010. p.

[8] S. Muhari and M.N. Hosen, Efficiency Level of BPRS in Indonesia Comparative Method SFA and DEA and its Correlation of

[9] CAMEL (Banking Journa; , Vol.18, N02 Mei 2014). p. 308-309.

[10] A. Baten, Efficiency and Productivity Change of Selected Online Banks in Bangladesh: A Nonparametric Malmquist Approach.

[11] Journal of Internet Banking and Commerce, Desember 2015, vol. 20, no. 3, p. 2

[12] R. Hidayat, Efficiency of Syariah Bank, (Bekasi: Gramata Publishing, 2014), p. 64

[13] J. P. Hughes and L. J. Mester, Efficiency in Banking: Theory, Practice, and Evidence. Prepared for the Oxford Handbook of

[14] Banking. 2008, p. 16.

[15] V.O. Odedokun, Evaluation Of Parametric Technique Of Technical Efficiency Measurement: Application To Smallholder

[16] Cotton Farmers in zamfara state, Nigeria, Int J Cur Res Rev, Vol 7, Issue 11, June 2015, h. 66. IJCRR Section: Healthcare Sci.

[17] Journal Impact Factor 4.016..

[18] I. M. Dashti, Imposing Monotonicity And Concavity Restrictions Into Stochastic Cost Frontiers: A Bayesian Approach,

[19] Dissertation, Kansas State University, Manhattan, Kansas, 1996, p. 22.

[20] A. H. Fadhlullah, Effeciency of Region Bank: Stochastic Frontier Approach, Significant Vol. 4 No. 1 April 2015, p. 6.

[21] A. N. Berger and D. B. Humphrey. (1997), "Efficiency of financial institutions: international survey and directions for future

[22] research", European Journal of Operational Research, Vol. 98 No. 2, pp. 175-212. 